\title{
Mind Maps to Improve Text Summarizing Learning Outcomes for 5th Grade Students
}

\author{
Upik Aimanah $^{1}$, Kuntoro ${ }^{2}$, Riptina Pawestri ${ }^{3}$, Desy Prastiti Setyarini ${ }^{4}$ \\ $\left\{\right.$ upik.aima@gmail.com ${ }^{1}$, kuntorosutaryo@gmail.com ${ }^{2}$, riptina.2305@gmail.com ${ }^{3}$, \\ ibunefarhan@gmail.com $\left.{ }^{4}\right\}$ \\ ${ }^{1}$ SD Negeri 1 Karangnangka \\ ${ }^{2}$ Universitas Muhammadiyah Purwokerto \\ ${ }^{3}$ SD Negeri 1 Bancarkembar \\ ${ }^{4}$ SD Negeri 1 Kejobong
}

\begin{abstract}
This study aims to determine student learning outcomes after applying mind map techniques in summarizing texts. This study used a pre-experimental method with a one group pretest-posttest design. The research subjects involved 16 students of 5th grade SD Negeri 1 Karangnangka. The data collection instrument was in the form of a text summarizing test. Sampling was carried out using a saturated sampling technique, which is a sampling technique when all members of the population are used as samples. The results of statistical tests with the Wilcoxon test $=0.05$, the asymp. Sig. (2-tailed) value was 0.000 . The significance value $<0.05$ means that there is a significant effect on improving student learning outcomes by applying mind map techniques to text summarizing learning.
\end{abstract}

Keywords: Mind map, Summarizing text, Learning Outcomes

\section{Introduction}

Summarizing is one of the writing skills that is trained in language skills in elementary schools. Students cannot make a summary if they do not read carefully and cannot distinguish the main idea and explanatory ideas. For students to have the ability to differentiate between levels of ideas to sharpen the variety of language and avoid unnecessary descriptions, a technique that is fast, creative, and easy to apply is needed. Methods that students need to learn and use to help plan, communicate, increase creativity, spare time, fathom issues, focus attention, organize and clarify contemplations, keep in mind way better, learn more rapidly and productively, and see the "whole picture" is with a mind map [1].

Mind maps are the imaginative note-taking method that creates it easy for us to keep in mind numerous data. Notes created with a mind map form a pattern of interrelated thoughts, with the most point within the center and the sub-topics and subtle elements being branches. Mind maps are colorful and use lots of pictures and symbols, so they look like works of art. Structured photographs and diagrams are considered to be more comprehensive than just words, and more precise to illustrate understanding of complex topics [2]. A good mind map can show the overall structure of a topic or problem with lines and pictures [3]. However, some argue that images and symbols are not very important in a mind map. Iconography is not so important to the participants' mind maps as is often theorized [4]. 
Based on research in China, mind mapping is also useful for improving students' academic achievement [5]. In another study also found, adopting a mind mapping strategy can significantly improve student achievement [6]. Meanwhile, in the application of mind mapping techniques in summarizing texts, in a study, it was found that learning to summarize legend texts using the mind mapping method experienced an increase in learning outcomes [7]. The use of mind mapping techniques also affects the students' summary writing skills in learning Indonesian in 5th-grade [8].

The purpose of this study was to determine student learning outcomes after applying mind map techniques in summarizing texts. This study hypothesizes is that there is an increase in learning outcomes after applying the mind map technique in learning to summarize the text in 5th-grade students of SD Negeri 1 Karangnangka.

\section{Research Methods}

This study used a pre-experimental method with a One Group Pretest-Postest design. In this design, there was only one group that was given treatment, where before treatment, the group was given a pre-test to determine the initial ability and a posttest to determine the ability after being given treatment. Thus the results of the treatment can be known more accurately because it can be compared with the situation before being treated. One group pretest-posttest research design is as follows [9].

Table 2.1. One Group Pretest-Posttest Design

\begin{tabular}{ccc}
\hline pretest & treatment & posttest \\
\hline $\mathrm{O}$ & $\mathrm{X}$ & $\mathrm{O}$ \\
\hline
\end{tabular}

The subjects of this study involved 16 students of 5th-grade SD Negeri 1 Karangnangka, which consisted of 10 male students and 6 female students. The sampling technique used in this research is saturated sampling. Saturated sampling is a sampling technique when all members of the population are used as samples [10].

The results of the study on 5th-grade students of SD Negeri 1 Karangnangka with a total research sample of 16 students obtained pre-test and post-test score data. The data collected from the research results are processed by quantitative methods. The requirement in determining the hypothesis test is that if the data is normally distributed, then the next hypothesis test uses the Parametric-Test, namely the paired sample t-test. But if the data distribution is not distributed.

\section{Results and Discussion}

Data on students' text summarizing ability were collected using a text summarizing test instrument. Data were collected through pretest and posttest after learning to summarize text with the mind map technique. After obtaining student scores, the next step is data processing.

The first stage is the Shapiro Wilk normality test to determine whether the data is normally distributed or not. If the data is normally distributed, then the hypothesis test uses the paired sample t-test, but if the data distribution is not normally distributed, the hypothesis test used is the Wilcoxon test. 
Table 1. Shapiro Wilk Normality Test

Tests of Normality

\begin{tabular}{lr|r|r|r|r|r}
\hline & \multicolumn{3}{c}{ Kolmogorov-Smirnova } & \multicolumn{3}{c}{ Shapiro-Wilk } \\
\cline { 2 - 8 } & Statistics & \multicolumn{1}{c}{ df } & \multicolumn{1}{c}{ Sig. } & Statistics & df & \multicolumn{1}{c}{ Sig. } \\
\hline Pretest & .275 & 16 & .002 & 0.811 & 16 & .004 \\
\hline Posttest & .304 & 16 & .000 & 0.751 & 16 & .001 \\
\hline
\end{tabular}

a. Lilliefors Significance Correction

Table 1 have shown the result of normality test. It indicates that the significance value for pretest and posttest is less than 0.05 , so it can be concluded that all research data are not normally distributed. Because the data are not normally distributed, we use the Wilcoxon test to test the hypothesis.

The hypothesis proposed in this study is that there is an increase in learning outcomes after the mind map technique is applied to text summarizing learning in 5th-grade students of SD Negeri 1 Karangnangka. To test the results of the hypothesis, there are decision-making criteria, namely, Ha Accepted if the test $<$ table.

Table 2. Wilcoxon test

\section{Test Statistics}

\begin{tabular}{lr} 
& \multicolumn{2}{c}{ Posttest - Pretest } \\
\hline $\mathrm{Z}$ & $-3.531 \mathrm{~b}$ \\
\hline asymp. Sig. (2-tailed) & .000 \\
\hline
\end{tabular}
a. Wilcoxon Signed Ranks Test
b. Based on negative ranks.

Based on the results of the Wilcoxon test above, it shows that the value of asymp. sig. (2tailed) is 0.000 . Because the value of 0.000 is smaller than 0.05 , it can be concluded that Ho is rejected and $\mathrm{Ha}$ is accepted. This means that there is a difference between the results of the pre-test and post-test, thus indicating that there is a significant effect of the use of mind mapping techniques on improving students' learning outcomes of summarizing texts.

The increase in student learning outcomes can also be seen from the average pre-test and post-test results where there is a significant change in the average learning outcomes before being given treatment and after being given treatment. The average students' pretest results were 69 while the posttest average of students after treatment was 90 .

There is an increase in students' learning outcomes to summarize students' texts because mind maps help distinguish levels of ideas to sharpen language variety and avoid unimportant descriptions. Brain and intelligence are two very related things. If brain function is used optimally, it will increase intelligence. Mind maps work by combining and developing the work potential of the two hemispheres of the brain in the learning process so that it becomes easy to organize and remember all forms of information, both information obtained through writing and orally. Mind maps make it easy to write down ideas, ideas, problems, solutions, or anything that comes to mind and burdens the subconscious brain which has been difficult to record on a piece of paper. 
In the process of summarizing texts, the use of mind mapping techniques motivates them to summarize in a fun way, increases vocabulary and creativity, then makes it easier to organize sentences and organize ideas. Using mind maps helps teachers to vary teaching methods to reach more diverse students [11]. The use of mind mapping in teaching also helps teachers improve their teaching, plan and evaluate lessons and make learning more entertaining [12]. The mind mapping technique is a cutting-edge, creative, and useful tool for students, educators, and researchers [13].

\section{Conclusions}

Based on the results of data processing and analysis of research data and discussions on the application of mind mapping techniques in learning to summarize texts as an effort to improve student learning outcomes, it was concluded that there was a significant increase in student learning outcomes after applying mind map techniques in summarizing texts. The increase in student learning outcomes can be seen from the difference in pretest scores with an average of 69 and posttest scores with an average of 90. The test results with the Wilcoxon test also strengthen the statement that there is an increase in learning outcomes where the results of the $t_{\text {test }}<t_{t a b l e}$ are obtained. Thus, the hypothesis of this study was accepted, namely an increase in learning outcomes after the mind map technique was applied to text summarizing learning in 5th-grade students of SD Negeri 1 Karangnangka.

\section{References}

[1] Buzan, Tony. Buku Pintar Mind Map. Jakarta: Gramedia; 2012. 6.

[2] Davies M. Concept mapping, mind mapping and argument mapping: what are the differences and do they matter?. Higher education. 2011 Sep 1;62(3):279-301.

[3] Nesbit JC, Adesope OO. Learning with concept and knowledge maps: A meta-analysis. Review of educational research. 2006 Sep;76(3):413-48.

[4] Abi-El-Mona I, Adb-El-Khalick F. The influence of mind mapping on eighth graders' science achievement. School Science and mathematics. 2008 Nov;108(7):298-312.

[5] Liu Y, Zhao G, Ma G, Bo Y. The effect of mind mapping on teaching and learning: A metaanalysis. Standard Journal of Education and Essay. 2014 Apr;2(1):17-31.

[6] Tee TK, Azman MN, Mohamed S, Mohamad MM, Yunos JM, Yee MH, Othman W. Buzan mind mapping: An efficient technique for note-taking. International Journal of Psychological and Behavioral Sciences. 2014 Jan 13;8(1):28-31.

[7] Wulandari R. MIND MAPPING DALAM PEMBELAJARAN MERINGKAS TEKS LEGENDA DI SMP N 1 BATANGAN (Doctoral dissertation, Universitas Negeri Semarang).

[8] Saharah S, Indihadi D. Penggunaan Teknik Mind Mapping pada keterampilan Menulis Ringkasan Siswa dalam Pembelajran Bahasa Indonesia. PEDADIDAKTIKA: Jurnal Ilmiah Pendidikan Guru Sekolah Dasar. 2019;6(1):9-15.

[9] Creswell JW. Research design: pendekatan metode kualitatif, kuantitatif, dan campuran. Yogyakarta: Pustaka Pelajar. 2016;230.

[10] Sugiyono. Metode Penelitian dan Pengembangan (Research and Development). Bandung: Alfabeta; $2019 ; 143$.

[11] Jones, Brett D, Ruff, Chloe, dan Snyder, Jennifer Dee. The Effects of Mind Mapping Activities on Students' Motivation. International Journal for the Scholarship of Teaching and Learning. 2012;6(1), 1-21.

[12] Keles Ö. Elementary teachers' views on mind mapping. International Journal of Education. 2012 Jan 1;4(1):93.

[13] Buran A, Filyukov A. Mind mapping technique in language learning. Procedia-Social and Behavioral Sciences. 2015 Oct 17;206:215-8. 
[14] Nirmala SD. Kemampuan Berpikir Kritis Siswa Kelas IV Se-Gugus 2 Purwasari Dalam Membaca Pemahaman Melalui Model Fives Dan Model Guided Reading. Dinamika Jurnal Ilmiah Pendidikan Dasar. 2019 Feb 12;10(2). 